\title{
ANC plans to boost prospects for black science students
}

Cape Town. In preparation for South Africa's first democratic elections in April, the African National Congress (ANC) has published proposals for increasing the number of black students taking university courses in science, engineering and medicine.

The proposals are expected to be formally adopted at the ANC's policy conference in March, and are aimed at correcting the imbalance between the number of black and white students in higher education. One way of doing this, says the ANC, would be to establish a national higher education council with the power to regulate the distribution of enrolments across sectors, institutions and disciplines.

The existing funding formula would be replaced by one incorporating subsidies for academic development programmes for disadvantaged students - who do not at present receive any government support - and redress institutional inequalities by favouring universities that have received relatively low levels of funding in the past.

The chances of such changes being implemented are good, as most polls put the ANC's support at about 60 per cent of the population. Some suggest is may be as high as two-thirds, the level of votes in the National Assembly required to enact a new constitution

Harold Wolpe, director of the University of the Western Cape's education policy unit, which was heavily involved in formulating the ANC's policy, says that the proposals also favour the gradual merger of universities and 'technikons' into a single sector, as has happened recently in the United Kingdom and Australia.

The merged institutions would come under the control of central government. In contrast, colleges offering certificates in teacher education, nursing, agriculture and technical subjects would, together with schooling, be the responsibility of the nine regional governments

The proposals say that South Africa should not divide universities into graduate and research institutions, or introduce teaching-only universities. But they do support the idea of centres of excellence, with some rationalization of university departments at the regional level.

A single national department of education and training would coordinate all educational programmes, and flexible access between sectors would be made easier by a national qualifications structure.

With regard to financing higher education, the ANC proposes to replace the present system, in which all students pay fees, with one in which fees are charged on a meanstested basis.

Michael Cherry

\section{Funding dispute could hold up biodiversity treaty}

London. Britain's environment minister, John Gummer, this week released an 'action plan' on biodiversity - one of four documents setting out how the government plans to meet commitments made at the Earth Summit held in Rio de Janeiro in 1992.

Behind the scenes, however, the government is threatening to delay ratification of the UN Biodiversity Convention until a dispute is resolved about the procedures by which developing countries are to be funded to meet their commitments under both this and the Climate Change Convention.

At the centre of the dispute is the Global Environment Facility (GEF), a \$1.3-billion fund set up by the World Bank in 1990 to pay the marginal costs of conserving biodiversity, mitigating climate change, pre-

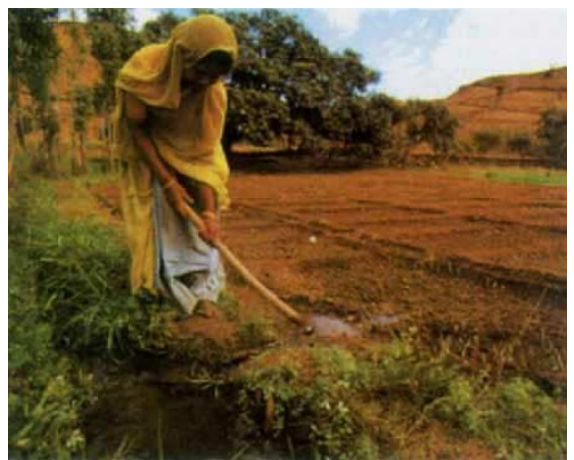

Home grown: most efforts to preserve biodiversity are small-scale.

serving the ozone layer and abating the pollution of international waters.

At the insistence of the member countries of the Organisation for Economic Cooperation and Development (OECD), the GEF emerged from the 1992 Earth Summit in Rio de Janeiro as the principal channel through which developing countries would be paid to meet obligations under the Biodiversity and Climate Change Conventions agreed at the meeting.

But the GEF - whose initial three-year pilot phase comes to an end in June - came in for some harsh criticisms at a meeting in Cartagena in Colombia last month, when an independent review team reported that it suffered from "inadequate" leadership and management, "complex, cumbersome and costly" decision-making processes and "diffused" accountability. The review claimed that developing countries were able to influence its operations "only on the margins".

British officials say they share these concerns, which have been voiced by government representatives and environmental groups in both developing and developed countries (including the United States).

But Britain and other OECD countries are insisting that the GEF must remain the principal financial mechanism serving the UN conventions. They are also determined that plans for restructuring the facility in the light of the evaluation will still ensure that funds are spent in a way that they approve.

Officials from Britain's Overseas Development Administration (ODA) are therefore warning that Britain will not ratify the Biodiversity Convention until the GEF's future is secured to its satisfaction. "I am sure that an effective replenishment and restructuring of the GEF would give the necessary reassurance to UK ministers [to ratify the convention]," says David Turner, head of environment policy at the ODA.

But the resolution of the GEF's problems may still be some way off. In order to solve the problems identified by the independent evaluators, the countries represented at Cartagena agreed that the GEF should set up a secretariat independent of the World Bank, reporting to a new executive council.

Talks broke down, however, over the relative representation on the council of the developed donor countries and the recipient developing and East European countries. In particular, France threatened to cut 30 per cent from its contribution to the \$2-billion replenishment target for the GEF's second phase if OECD representation fell below half of the 30 seats.

Following further discussion, the OECD countries have confirmed their commitment to the \$2-billion target, and expressed their desire to resume negotiations with the developing nations. As a result, talks on the future of the GEF are due to resume in February. One possible compromise is a 31 seat executive council, in which the recipient countries would have 16 seats. But the outcome is still uncertain.

Critics of Britain's position argue that it is trying to use the GEF to limit its support for international efforts to preserve biodiversity. "The financial obligations and opportunities created by the Biodiversity Convention go far beyond those offered by the GEF," says Tony Juniper of Friends of the Earth.

Alistair Graham of the Biodiversity Coalition, based in Australia, claims that, even with its new status, the GEF will still be almost entirely run by World Bank staff used to overseeing large development projects, and lacks sufficient skills and experience to support small-scale conservation projects run by local communities.

Graham and others are urging the creation of a new fund directly controlled by the signatories of the Biodiversity Convention - precisely the type of move that Britain, and several of its OECD partners, are determined to avoid.

Oliver Tickell 